\title{
Human Capital and SME Performance: Mediating Effect of Entrepreneurial Leadership
}

DOI: 10.7595/management.fon.2020.0009

Abstract:

Research Question: The paper investigates the relationships between human capital and SME performance, introducing into the analysis the mediating effect of entrepreneurial leadership in the specific context of a transitional economy. Motivation: The research of the mediating effect of entrepreneurial leadership contributes to a better understanding of the relationships between human capital and SME performance. As there is a small number of studies that have examined the role of entrepreneurial leadership in SMEs, the need for investigation is obvious. In addition, empirical evidence of the impact of human capital on SME performance is limited. Idea: Since leadership is considered to be a key determent of organisation growth, it is relevant to identify the relevance of entrepreneur's leadership style and characteristics, as well as its role in the relationship between human capital components and success of SMEs in Serbia. Data: The study included 110 employees in Serbian small and medium-sized enterprises with up to 50 employees. A questionnaire was used to measure the employees' attitude towards human capital, entrepreneurial leadership, and organizational performance, as well as socio-demographic variables. Tools: The data were prepared and analysed using statistical software IBM SPSS 24.0. Statistical data processing methods used in this paper are descriptive statistics, reliability analysis and regression analysis. Findings: The results of the analysis indicate that human capital has an indirect impact on organisational performance through the mediating effect of entrepreneurial leadership. Contribution: The results can be used in making future decisions, measures and standards related to human resource management in the context of transitional economies, as well as to help entrepreneurs to lead their employees effectively and ,,,,survive in today's turbulent business environment.

Keywords: Entrepreneurial leadership, human capital, SME performance, small- and medium-sized enterprises (SMEs)

JEL Classification: E22, E24, L26

\section{Introduction}

The essential role of entrepreneurs is based on understanding of the situation, implementation of business ideas and management of growth and enterprise development. In the initial stages of starting ,a new venture, an entrepreneur usually faces the problem of the lack and limitation of financial and material resources (Townsend, Busenitz \& Arthurs, 2010), and the main asset and its advantage over existing competitors on the market is precisely the human capital.

Human capital implies a set of competencies (knowledge, skills, abilities) and other individual attributes that employees have (O'Sullivan \& Sheffrin, 2007), acquired through the attainment of various education programmes, workplace training and acquisition of other experiences (Becker, 1964). Mincer marked a human capital as the cause of the inequality of income among employees (Mincer, 1958). An upgrade to his work and achievements is the development of the human capital theory, which was developed to determine the importance of investment in education (Becker, 1964; Schultz, 1961), which contributes to the differentiation of employees based on the quality and quantity of knowledge they possess. On the basis of set theoretical postulates, human capital represents the economic value that employees provide to their employers, which at the same time rejects the traditional understanding, by which human capital expenditure is viewed as an expense rather than an investment (Phillips, 2005).

Since leadership is classified as one of the key factors for the growth and development of each organization (Harrison et al., 2015) and human capital as one of the factors indicating a clear distinction between en- 
trepreneurs and non-entrepreneurs (Matricano, 2016) and a valuable resource in obtaining extraordinary performances (Kato et al., 2006; Unger et al., 2011), the question of the role of the leadership style of entrepreneurs and their character traits in the relationship between the two variables: human capital and SME performance is raised.

By reviewing the results of the previous empirical studies, a gap is identified that is based on the insufficiently investigated influence of the entrepreneur's style on SME performance, as well as the mediator of the relationship between the intangible assets and the achieved results of SMEs. Accordingly, the aim of research in the article is to explain the role of entrepreneurial leadership, as a mediator of the relationship between human capital components and SME performance in the case of a transition economy.

\section{Theoretical Background and Hypotheses}

\subsection{Human capital in SMEs}

There are several reasons why the issue of investment in human capital, that is, the improvement of human capital is relevant to the field of entrepreneurship. First, human capital is vital to discovering and creating entrepreneurial opportunities. Second, human capital helps in the exploitation of opportunities, defines the use of available resources, and thus the entire process of starting a new venture. Third, human capital helps accumulate new knowledge and achieve competitive advantage. Therefore, it is quite logical why the quality of human capital of members of the entrepreneurial team is the most common criterion used by capitalists in evaluating the performance of the venture (Marvel, Davis \& Sproul, 2016).

Since the importance of investing in people is recognized (Becker, 1964; Schultz, 1961), better human capital means that employees have a wider range of relevant knowledge and skills, which will probably contribute to higher growth prospects (Kato et al., 2006; Rauch \& Rijsdijk, 2013; Unger et al., 2011) and enterprise sustainability on the business scene (Bates, 1990, Astebro \& Bernhardt, 2003). Colombo and Grilli (2005) state that individuals with a higher degree and quality of human capital have a more developed ability to reason and perceive opportunities in the environment, which represents the unique, and very often the key competence of the founders of the venture. As a kind of implication of conducted research and studies, the fact is that the ability, and in a broader sense, knowledge and skills of entrepreneurs represent a valuable resource in achieving superior performance, which partly compensates for the lack of business experience and resources, which are in turn often one of the most important arguments in the presentation in front of investors (Kato et al., 2006).

\subsection{Entrepreneurial leadership}

Creating a syntagm and developing a concept of entrepreneurial leadership is actually a result of connection between the leadership and entrepreneurship. Leadership involves making influence and motivating followers in order to engage in the achievement of organizational goals (Stojanovic - Aleksic, 2007). On the other hand, entrepreneurship, as a scientific field, deals with determining the manner in which they discover and exploit opportunities for the creation of future products and services (Shane \& Venkataraman, 2000). According to given definitions of these phenomena, it is possible to create a whole list of attributes and activities, as a kind of synergy of entrepreneurship and leadership, such as the following: vision, focus on identifying opportunities, impact, planning, motivation, focus on achievement, creativity, flexibility, patience, perseverance, risk taking, uncertainty tolerance, self-confidence, proactivity and internal control locus (Renko, El Tarabishy, Carsrud \& Brännback, 2015).

The identified correlation and convergence of the area of entrepreneurship and leadership unambiguously rely on the trend of growing interest in the concept of entrepreneurial leadership. Entrepreneurial leadership implies a unique way of thinking and skills that help entrepreneurial leaders to identify, develop and implement new business opportunities (Thornberry, 2006). Roomi \& Harrison (2011) defines entrepreneurial leadership as a process of formulating and communicating a vision in order to engage teams in order to identify, develop, and exploit the opportunity, which leads to the achievement of a competitive advantage. Similarly to the foregoing, Renko, El Tarabishy, Carsrud \& Brännback (2015) point out that entrepreneurial leadership implies influence on and direction of group members in achieving organizational goals that include identifying and exploiting entrepreneurial opportunities.

\subsection{Entrepreneurial leadership and performance}

Bearing in mind the growing interest in the concept of entrepreneurial leadership, Huang, Ding and Chen (2014) have identified several dimensions of this leadership style, by which they explain the leader's beha- 
viour and his actions in the context of entrepreneurial ventures relevant for its survival and development. First, the leader has to set high standards and work hard in order to achieve the desired performance. An entrepreneurial leader needs to be capable of identifying opportunities that will result in generating sustainable competitive advantage (Ireland, Covin \& Kuratko, 2009 in Huang et al., 2014). Second, respecting certain circumstances, the leader has to anticipate possible future events and formulate the desired image in the future. Third, apart from formulating the vision and respecting a certain degree of uncertainty, an entrepreneurial leader has to inspire his followers and persuade them to accept his viewpoint (Gupta, MacMillan \& Surie, 2004 in Huang et al., 2014). Respecting the needs of followers and building trust among team members, an entrepreneurial leader enables the promotion of entrepreneurial self-efficacy and team spirit (Breugst, Domurath, Patzelt \& Klaukien, 2012 in Huang et al., 2014). Finally, the leader ought to integrate people or things into cohesiveness in order to provide support from key stakeholders and obtain critical resources and information. By maintaining permanent contact with an internal and external environment, an entrepreneurial leader can anticipate potential resistance, which will provide for the success in exploiting the opportunity and creating value (Kansikas et al., 2012 in Huang et al., 2014).

Based on the previous elaboration of the established dimensions of the entrepreneurial leadership, a clear, unequivocal conclusion is drawn that the entrepreneur as a leader plays an important role in determining the achieved performance. First, an entrepreneurial leader defines challenges, absorbs uncertainty, contributes to the flexibility and commitment of team members. Second, an entrepreneurial leader is very tolerant of uncertainty, persistent, creative, and enthusiastic and dynamic leader with high networking and communication capabilities, and these allow him to build entrepreneurial culture and organization. Third, an entrepreneurial leader is prone to implementing change and introducing innovations, accepting risk, and often has an aggressive and proactive approach to competitors. Fourth, an entrepreneurial leader behaves as an agent of change, enhancing the creativity of the team and encouraging members to participate in problem solving, defining quality standards, setting goals (Chen, 2007).

\subsection{The mediating role of entrepreneurial leadership}

We expect an entrepreneurial leadership to mediate the relationship between human capital and performance in the following ways. In the context of a new business venture, the entrepreneur represents the main driving force of innovation, which is fundamental to the continuity and sustainability of entrepreneurial ventures (Renko et al., 2015). Since the entrepreneur is the central figure of the entrepreneurial process, there are two reasons that point out the positive correlation between the human capital of the entrepreneur and the performance of the entrepreneurial venture: first, entrepreneurs are residual claimants of the substance of the enterprise, and consequently there is a strong incentive to exploit their human capital for the benefit of the enterprise; second, entrepreneurs appropriate an investment income, which is why they continuously seek to achieve a fair yield with an acceptable return period for investments, with a minimal use of external sources (Cliff, 1998).

The interest in entrepreneurial leadership has grown, since the efforts of the expert public so far have been focused only on the analysis of leadership styles in large organizations and the entrepreneurial behaviour of middle management of eminent corporations (Gupta, MacMillan, \& Surie 2004). In SMEs, the role of leadership is probably more significant than in large corporations, especially since in smaller organizations the line of separation of responsibility of leaders and managers is rather blurred (Watson, Storey, Wynarczyk, Keasey \& Short, 1994).

Therefore, we cannot talk about the success of entrepreneurial venture if the assumption of effective implementation of entrepreneurial leadership is not met (Cogliser \& Brigham 2004). The importance of the created leadership style can also be justified by the current situation characterized by the internal environment of the enterprise, which primarily relates to a lack of standardized operational procedures, insufficiently developed managerial practice and an inadequately designed organizational structure that will enable recovery in case of failure (Renko et al., 2015).

Entrepreneurial leaders are often associated with the transformational style of leadership (Ling et al., 2008; Renko et al., 2015). Namely, a positive correlation between the transformational and the entrepreneurial leaderships in the field of their influence on the effectiveness of the process of formulation and implementation of the strategy, communication and intreperson relation within the enterprise was recognised (Smit, De Coning \& Visser, 2005).

According to the transactional-transformation theory, transformation leaders influence the performance of a new enterprise by articulating a defined vision, great inspirational power and overcoming barriers such as risk aversion and status quo (Ensley, Pearce \& Hmieleski, 2006). Compared to the transformational style, the transaction leader uses contingency rewards, which include material and non-material rewards for follo- 
wers, to ensure the survival and growth of a new venture (Jansen, Vera \& Crossan, 2009). However, the effectiveness of transformational and transactional leaderships usually depends on the given organizational context, whereby the distinction is reflected in the willingness of the leader to carry out his entrusted tasks (Gupta et al., 2004). Contrary to the above-mentioned styles, entrepreneurial leadership is based on the assumption that a leader often has to act at a given moment without prior preparation and systematic planning of his activities (Gupta et al., 2004; Wang, Tee \& Ahmed, 2012). This scenario corresponds to the environment in which there are new ventures faced with a high degree of risk and a number of barriers to growth and development of the venture. In addition, this clearly indicates the importance of effective entrepreneurial leadership in achieving the performance of a new venture (Huang et al., 2014; Feng Jing, Avery \& Bergsteiner, 2011), but also the importance of developing the dimensions of entrepreneurial leadership as a contemporary paradigm of survival on the contemporary market scene (Chen, 2007).

Based on the given literature review and research subject, the following hypotheses are defined:

$\mathrm{H} 1$ : Human capital has a statistically significant impact on the SME performance.

H2: Entrepreneurial leadership has a statistically significant impact on the SME performance.

H3: The impact of human capital on the SME performance is greater in the case of effective entrepreneurial leadership.

\section{Methodology}

According to the given theoretical review, the subject of research in the paper is to explain the role of entrepreneurial leadership as a mediator of the relationship between human capital components and the SME performance. Participants in this research were employees working between 5 and 12 years in SMEs that actively operate in Central and Southern Serbia.

Primary data were collected using an exploratory research technique - a survey. The research was conducted in the period July-September 2018 using the instrument of the survey technique - a questionnaire, which was specially conceived for this research. The selection of SMEs was based on availability criterion - we have selected enterprises in Central and Southern Serbia whose employees agreed to take part in the research. The questionnaire, which is distributed to employees, consists of a total of 29 statements, while the degree of agreement with these statements was expressed on the five-point Likert scale ( 1 absolutely disagree, 5 absolutely agree). The total sample number of 110 respondents was collected.

Regarding the structure of the sample by activity, that is, belonging to a particular business sector, the sample includes 22 enterprises (20\%) who are engaged in production activities. The largest number of enterprises that are incorporated in the sample are in the wholesale and retail sectors (48\%), while 35 enterprises are engaged in the service activities. Below is a description of the structure of the sample from the aspect of the respondents who took part in the given research.

Table 1: Characteristics of respondents: summarized review

\begin{tabular}{|c|c|c|}
\hline Variable & Frequency & Percent (\%) \\
\hline \multicolumn{3}{|l|}{ Gender } \\
\hline Male & 62 & $56.4 \%$ \\
\hline Female & 48 & $43.6 \%$ \\
\hline \multicolumn{3}{|l|}{ Level of education } \\
\hline Primary or secondary education & 78 & $70.9 \%$ \\
\hline Higher education & 29 & $26.4 \%$ \\
\hline Master or PhD & 3 & $2.7 \%$ \\
\hline \multicolumn{3}{|l|}{ Age distribution (years) } \\
\hline $18-30$ & 7 & $6.4 \%$ \\
\hline $31-50$ & 75 & $62.7 \%$ \\
\hline 51 or more & 28 & $20.0 \%$ \\
\hline
\end{tabular}

Source: Authors' own calculation based on the survey

Statistical data processing was performed with the computer support of the statistical package for social sciences IBM SPSS Statistics, Version 23 (Statistical Package for Social Sciences). In order to determine the statistical significance, the confidence levels were used $\alpha=0,05, \alpha=0.01$. The following statistical methods were applied in the research: descriptive statistics, reliability analysis and multiple regression. 
Table 2: Variables, items and descriptive statisics

\begin{tabular}{|c|c|c|}
\hline Variables and items & $\begin{array}{c}\text { Aritmetic } \\
\text { mean }\end{array}$ & $\begin{array}{l}\text { Standard } \\
\text { deviation }\end{array}$ \\
\hline $\begin{array}{l}\text { Framing the challenge } \\
\text { 1. Your supervisor defines high standards in realizing business results. } \\
\text { 2. Your superior strives for continuous improvement in business results. }\end{array}$ & 4.0864 & 0.73215 \\
\hline $\begin{array}{l}\text { Absorbing uncertainty } \\
\text { 3. Your supervisor formulates a clear vision and communicates with other } \\
\text { employees. } \\
\text { 4. Your superior anticipates possible future events well. } \\
\text { 5. Your supervisor assists employees in the organizational change process. }\end{array}$ & 4.0848 & 0.68987 \\
\hline $\begin{array}{l}\text { Underwriting } \\
\text { 6. Your supervisor convinces others to accept his or her opinion and that of } \\
\text { other employees. } \\
\text { 7. Your supervisor has built good relationships with other employees. } \\
\text { 8. Your supervisor encourages your employees by giving helpful advice. }\end{array}$ & 4.2303 & 0.67841 \\
\hline $\begin{array}{l}\text { Building commitment } \\
\text { 9. Your supervisor motivates and encourages your employees to fulfill their work } \\
\text { responsibilities. } \\
\text { 10. Your supervisor encourages team work in your firm. } \\
\text { 11. Your supervisor encourages employees to accept organisational values and } \\
\text { beliefs. }\end{array}$ & 4.1212 & 0.67234 \\
\hline $\begin{array}{l}\text { Defining gravity } \\
\text { 12. Your superiors strive for greater cohesion among employees. } \\
\text { 13. Your superior is optimistic about possible business results. } \\
\text { 14. Your supervisor makes decisions quickly and firmly follows his/her decisions. }\end{array}$ & 4.2030 & 0.58888 \\
\hline $\begin{array}{l}\text { SME performance } \\
\text { 1. The growth rate of sales is higher than the competitors' rate. } \\
\text { 2. Market share is higher than the participation of competitors. } \\
\text { 3. Pay great attention to research and development functions, technological } \\
\text { leadership and innovation. } \\
\text { 4. Introduce new products / services that meet the needs of your consumers / } \\
\text { clients. }\end{array}$ & 3.8258 & 0.62906 \\
\hline $\begin{array}{l}\text { Skills, knowledge \& expertise (SKE) } \\
\text { 1. Knowledge gained through formal education is useful to you in accomplishing } \\
\text { everyday tasks. } \\
\text { 2. You have skills that are relevant for your working performance. } \\
\text { 3. You constantly improve your knowledge and skills. }\end{array}$ & 3.7036 & 0.66124 \\
\hline $\begin{array}{l}\text { Intellectual agility } \\
\text { 4. In the troubleshooting process, you are always ready to apply alternative } \\
\text { solutions. } \\
\text { 5. You tend to look at the problem identified from different angles. } \\
\text { 6. When completing your work assignments, you regularly apply new, unusual } \\
\text { and innovative solutions. }\end{array}$ & 4.0682 & 0.59133 \\
\hline $\begin{array}{l}\text { Attitude } \\
\text { 7. You perceive your working tasks as a challenge and a chance to prove your } \\
\text { skills. } \\
\text { 8. The achieved results give you extra energy to accomplish your working tasks } \\
\text { in the future. } \\
\text { 9. The job you do gives you a sense of accomplishment and personal fulfillment. } \\
\text { 10. The job you do positively contributes to your status in society. } \\
\text { 11. The job you do leaves you plenty of time to devote to your family and your } \\
\text { personal life. }\end{array}$ & 4.1403 & 0.66360 \\
\hline
\end{tabular}


We measured the entrepreneurial leadership variable using 14 items according to a previous research by Huang et al. (2014). These statements correspond to the explained roles of the entrepreneurial leader (e.g., framing the challenge, absorbing uncertainty, underwriting, building commitment, defining gravity). Cronbach's was 0.934 . We measured the SME performance by using the respondent's subjective perceptions. The respondents were asked to evaluate the financial and non-financial indicators on the basis of their personal understanding of the situation in the current enterprise (Tang et al., 2017; Huang et al., 2014). We measured the performance by using 4 items. Cronbach's was 0.867 . We measured human capital by using 11 items comprising the components of skills, knowledge \& expertise (SKE), intellectual agility and attitude (Edvinsson \& Malone, 1997; Tovstiga \& Tulugurora, 2007; Khalique et al., 2015). Respondents were asked to evaluate the entrepreneur's attitudes, knowledge and skills, his/her level of creativity, innovation and flexibility, and express degree of agreement with the attitudes of entrepreneurs and their motivation to manage the venture. Cronbach's was 0.862 .

\section{Results and Discussion}

In order to test the defined hypotheses, a multiple standard regression was performed. Regression model 2 examines the nature and strength of the relationship between the identified components of human capital and the SME performance. The selected independent variables determine the performance of the enterprise in $24.8 \%$ of cases $\left(R^{2}=0.248\right)$. Multicolorarity is not a problem, given that the variance inflation factor is less than 5 (VIF = 1.392). The obtained results indicate that the analyzed human capital components have a statistically significant positive impact on SME performance, thus confirming the $\mathrm{H} 1$ hypothesis.

Regression model 3 was created to determine the statistically significant influence of entrepreneurial leadership on SME performance. The SME performance as a dependent variable was determined by a given independent variable in $39.3 \%$ of cases $\left(R^{2}=0.393\right)$. The results of a simple regression analysis unambiguously imply that the entrepreneurial leadership style has a statistically significant strong positive effect on perfromance, thus confirming the $\mathrm{H} 2$ hypothesis.

A method developed by Baron and Kenny (1986) was used to analyze the median effect of the identified dimensions of entrepreneurial leadership in the relationship between human capital components and the performance of an entrepreneurial venture. The above procedure is based on the implementation of the multiple regression analysis, which implies: (1) determining the impact of human capital components on the entrepreneurial leadership style; (2) determining the impact of human capital components on the SME performance; (3) determining the influence of entrepreneurial leadership on the SME performance; (4) determining the impact of human capital components and entrepreneurial leadership on the SME performance. According to Baron and Kenny (1986), the mediator effect exists when in the last step there is a decrease in the influence of an independent variable on the dependent variable or the effect of an independent variable on the dependent variable becomes insignificant. In accordance with the procedure described and the results of multiple regression analysis, it can be concluded that hypothesis H3 is confirmed, since in the last step (model 4) the human capital component has an insignificant effect on the SME performance.

Table 3: Results of regression analysis (mediating variable: entrepreneurial leadership)

\begin{tabular}{|c|c|c|c|c|}
\hline Variable & $\begin{array}{c}\text { Model 1: } \\
\text { dependent } \\
\text { variable, } \\
\text { entrepreneurial } \\
\text { leadership }\end{array}$ & $\begin{array}{c}\text { Model 2: } \\
\text { dependent } \\
\text { variable SME } \\
\text { performance }\end{array}$ & $\begin{array}{c}\text { Model 3: } \\
\text { dependent } \\
\text { variable SME } \\
\text { performance }\end{array}$ & $\begin{array}{c}\text { Model 4: } \\
\text { dependent } \\
\text { variable SME } \\
\text { performance }\end{array}$ \\
\hline $\begin{array}{l}\text { Skills, knowledge \& } \\
\text { expertise (SKE) }\end{array}$ & 0.115 & $0.040^{\star}$ & & -0.023 \\
\hline Intellectual agility & 0.161 & $0.292^{\star}$ & & 0.204 \\
\hline Attitude & $0.464^{* *}$ & $0.225^{*}$ & & -0.029 \\
\hline $\begin{array}{l}\text { Entrepreneurial } \\
\text { leadership }\end{array}$ & & & $0.627^{\star *}$ & $0.547^{* *}$ \\
\hline $\mathrm{R}^{2}$ & 0.436 & 0.248 & 0.393 & 0.417 \\
\hline ANOVA F & $27.294^{\star \star}$ & 19.864 ** & $70.027^{\star \star}$ & $18.784^{\star \star}$ \\
\hline
\end{tabular}

Agenda: ${ }^{* *} p<0.01 ;{ }^{*} p<0.05$. Beta coefficient is shown. 


\section{Practical Implications and Limitations}

The results of the conducted research have important practical implications. First, the obtained results are only a kind of confirmation of the dominant position that non-material resources constitute a key source of achieving superior performance. In the same way, encouraging investment in human capital is an existential condition of modern organization, especially in case of entrepreneurial ventures, which are inevitably faced with limited possibilities of creating a favorable competitive position in today's big "rivals". Second, in addition to attending regular education programmes, it is necessary to concentrate efforts on developing innovative abilities, recognizing new, unusual solutions, enabling entrepreneurial ventures to take a unique position and contribute to their distinction in the context of intensifying market pressures. Third, since knowledge, skills and abilities are just a tool in the hands of employees, it is necessary to motivate employees to ensure an effective implementation of existing competences. When asked about the motivation of employees, the request for the development of the appropriate style of leadership of the owner, i.e., the founder of the entrepreneurial venture, is added. Since the substance of a particular style of leadership consists of personal characteristics, but also of the knowledge and skills of the leaders, it is necessary to ensure that the entrepreneur as the carrier of the entrepreneurial process (1) has confidence in his followers; (2) formulates challenging but realistic goals; (3) clearly communicates the defined vision and directs the work of his/her followers towards its realization; (4) creates a strong sense of community among employees and contributes to building a sense of commitment to the venture.

As other research in the field of social sciences, the research conducted for the purposes of this paper has a number of limitations. The first limitation refers to the structure of the sample from the aspect of the core business. The sample constitutes entrepreneurial ventures that operate within the manufacturing, trade and services sectors, and each of these sectors has several specificities, which primarily relate to the performance of certain operations that may affect the observed variables in the survey. Another potential limitation is the approach to performance measurement. The questionnaires were filled out by employees when asked to state their degree of agreement with defined items, which, among other things, related to the performance of the observed enterprise (Wiklund \& Shepherd, 2003; Huang et al., 2014; Tang et al., 2017). On the other hand, there are studies in which the indicators used in the analysis were published in the official financial statements (Chen, Cheng \& Hwang, 2005; Besharati, Kamali, Mazhari, \& Mahdavi, 2012; Komnenic \& Pokrajcic, 2012). The third limitation refers to the size of the sample. Compared to the studies previously carried out in this area, the need to increase the number of interviewed respondents is imminent. This constraint is due to the relatively underdeveloped business culture and the closure of external communications companies, which inevitably reflects the limited number of options for collecting questionnaires and increasing the number of units in the sample.

\section{Conslusion}

The importance of the conducted empirical research refers to a kind of affirmation of the entrepreneur as the key figure of an entrepreneurial venture, one who should possess certain personal predispositions, knowledge, skills and abilities. The contribution of the given research to the existing literature is clear. Since in entrepreneurial activity there is a huge potential for improving national competitiveness, it is important to emphasize the figure of entrepreneurs as "fighters" for survival in the modern market arena. Based on the obtained results of the multiple regression analysis it can be concluded that the development of human capital represents a necessary but insufficient condition for achieving superior performance. The leadership ability of entrepreneurs has an important role in an efficient and effective application of available knowledge, skills and capabilities of employees, which is why it is important to maintain the relations between entrepreneurs (leaders) and employees (followers).

\section{Acknowledgements}

This paper is part of an interdisciplinary research project (Number III41010), financed by the Republic of Serbia's Ministry of Education, Science and Technological Development. 


\section{REFERENCES}

[1] Astebro, T., \& Bernhardt, I. (2003). Start-up financing, owner characteristics, and survival. Journal of Economics and Business, 55(4), 303-319. DOI: 10.1016/S0148-6195(03)00029-8

[2] Baron, R. M., \& Kenny, D. A. (1986). The moderator-mediator variable distinction in social psychological research: Conceptual, strategic, and statistical considerations. Journal of personality and social psychology, 51(6), 1173. DOI: 10.1037/0022-3514.51.6.1173

[3] Bates, T. (1990). Entrepreneur human capital inputs and small business longevity. The review of Economics and Statistics, 551-559.

[4] Becker, G. S. (1964). Human capital: a theoretical analysis with special reference to education. New York: Columbia University Press for NBER.

[5] Besharati, E., Kamali, S., Mazhari, R. H., \& Mahdavi, S. (2012). An investigation of relationship between intellectual capital and innovation capital with financial performance and value of companies accepted in Tehran Stock Exchange. Journal of Basic and Applied Scientific Research, 2(2), 1241-1245.

[6] Breugst, N., Domurath, A., Patzelt, H., \& Klaukien, A. (2012). Perceptions of entrepreneurial passion and employees' commitment to entrepreneurial ventures. Entrepreneurship Theory and Practice, 36(1), 171-192. DOI: 10.1111/j.1540-6520.2011.00491.x

[7] Chen, M. C., Cheng, S. J., \& Hwang, Y. (2005). An empirical investigation of the relationship between intellectual capital and firms' market value and financial performance. Journal of intellectual capital, 6(2), 159-176. DOI: 10.1108/14691930510592771

[8] Chen, M. H. (2007). Entrepreneurial leadership and new ventures: Creativity in entrepreneurial teams. Creativity and Innovation Management, 16(3), 239-249. DOI: 10.1111/j.1467-8691.2007.00439.x

[9] Cliff, J. E. (1998). Does one size fit all? Exploring the relationship between attitudes towards growth, gender, and business size. Journal of business venturing, 13(6), 523-542. DOI: 10.1016/S08839026(97)00071-2

[10] Cogliser, C. C., \& Brigham, K. H. (2004). The intersection of leadership and entrepreneurship: Mutual lessons to be learned. The Leadership Quarterly, 15(6), 771-799. DOI: 10.1016/j.leaqua.2004.09.004

[11] Colombo, M. G., \& Grilli, L. (2005). Founders' human capital and the growth of new technology-based firms: A competence-based view. Research policy, 34(6), 795-816. DOI: 10.1016/j.respol.2005.03.010

[12] Edvinsson, L., \& Malone, M. S. (1997). Intellectual capital: The proven way to establish your company's real value by finding its hidden brainpower. Piatkus.

[13] Ensley, M. D., Pearce, C. L., \& Hmieleski, K. M. (2006). The moderating effect of environmental dynamism on the relationship between entrepreneur leadership behavior and new venture performance. Journal of Business Venturing, 21(2), 243-263. DOI: 10.1016/j.jbusvent.2005.04.006

[14] Feng Jing, F., Avery, G. C., \& Bergsteiner, H. (2011). Organizational climate and performance in retail pharmacies. Leadership \& Organization Development Journal, 32(3), 224-242. DOI: $10.1108 / 01437731111123898$

[15] Gupta, V., MacMillan, I. C., \& Surie, G. (2004). Entrepreneurial leadership: developing and measuring a cross-cultural construct. Journal of Business Venturing, 19(2), 241-260. DOI: 10.1016/S08839026(03)00040-5

[16] Harrison, R., Leitch, C., \& McAdam, M. (2015). Breaking glass: Toward a gendered analysis of entrepreneurial leadership. Journal of Small Business Management, 53(3), 693-713. DOI: 10.1111/jsbm.12180

[17] Huang, S., Ding, D., \& Chen, Z. (2014). Entrepreneurial leadership and performance in Chinese new ventures: A moderated mediation model of exploratory innovation, exploitative innovation and environmental dynamism. Creativity and Innovation Management, 23(4), 453-471. DOI: 10.1111/caim.12085

[18] Ireland, R. D., Covin, J. G., \& Kuratko, D. F. (2009). Conceptualizing corporate entrepreneurship strategy. Entrepreneurship theory and practice, 33(1), 19-46. DOI: 10.1111/j.1540-6520.2008.00279.x

[19] Jansen, J. J., Vera, D., \& Crossan, M. (2009). Strategic leadership for exploration and exploitation: The moderating role of environmental dynamism. The Leadership Quarterly, 20(1), 5-18. DOI: 10.1016/j.leaqua.2008.11.008

[20] Kansikas, J., Laakkonen, A., Sarpo, V., \& Kontinen, T. (2012). Entrepreneurial leadership and familiness as resources for strategic entrepreneurship. International Journal of Entrepreneurial Behavior \& Research, 18(2), 141-158. DOI: 10.1108/13552551211204193

[21] Kato, M., Okamuro, H., \& Honjo, Y. (2006). Does Founders' Human Capital Matter for. Journal of Economics and Business, 55, 303-319. DOI: 10.1111/jsbm.12094

[22] Khalique, M., Bontis, N., Nassir bin Shaari, J. A. \& Isa, A. H. Md. (2015). Intellectual capital in small and medium enterprises in Pakistan. Journal of Intellectual Capital, 16(1), 224-238. DOI: 10.1108/JIC01-2014-0014

[23] Komnenic, B., \& Pokrajcic, D. (2012). Intellectual capital and corporate performance of MNCs in Serbia. Journal of Intellectual Capital, 13(1), 106-119. DOI: 10.1108/14691931211196231 
[24] Ling, Y., Simsek, Z., Lubatkin, M. H., \& Veiga, J. F. (2008). The impact of transformational CEOs on the performance of small-to medium-sized firms: Does organizational context matter?. Journal of Applied Psychology, 93(4), 923. DOI: 10.1037/0021-9010.93.4.923

[25] Marvel, M. R., Davis, J. L., \& Sproul, C. R. (2016). Human capital and entrepreneurship research: A critical review and future directions. Entrepreneurship Theory and Practice, 40(3), 599-626. DOI: 10.1111/etap.12136

[26] Matricano, D. (2016). The impact of intellectual capital on start-up expectations. Journal of Intellectual Capital, 17(4), 654-674. DOI: 10.1108/JIC-04-2016-0040

[27] Mincer, J. (1958). Investment in human capital and personal income distribution. Journal of political economy, 66(4), 281-302.

[28] O Sullivan, A., \& Sheffrin, S.M., (2007). Economics: Principles in action, New Jersey: Pearson Prentice Hall.

[29] Phillips, J. J. (2005). Investing in your company's human capital: Strategies to avoid spending too little-or too much. AMACOM Div American Mgmt Assn.

[30] Rauch, A., \& Rijsdijk, S. A. (2013). The effects of general and specific human capital on long term growth and failure of newly founded businesses. Entrepreneurship Theory and Practice, 37(4), 923-941. DOI: $10.1111 / \mathrm{j} .1540-6520.2011 .00487 . x$

[31] Renko, M., El Tarabishy, A., Carsrud, A. L., \& Brännback, M. (2015). Understanding and measuring entrepreneurial leadership style. Journal of Small Business Management, 53(1), 54-74. DOI: $10.1111 / \mathrm{jsbm} .12086$

[32] Roomi, M. A., \& Harrison, P. (2011). Entrepreneurial leadership: What is it and how should it be taught? International eview of Entrepreneurship, 9(3),1-43.

[33] Schultz, T. W. (1961). Investment in Human Capital, The American Economic Review, 51(1), 1-17.

[34] Shane, S., \& Venkataraman, S. (2000). The promise of entrepreneurship as a field of research. Academy of management review, 25(1), 217-226. DOI: 10.5465/amr.2000.2791611

[35] Smit, E., De Coning, T. J., \& Visser, D. J. (2005). The relationship between the characteristics of the transformational leader and the entrepreneur in South African SMEs. South African Journal of Business Management, 36(3), 51-63.

[36] Stojanovic - Aleksic, V. (2007). Liderstvo i organizacione promene. Kragujevac: Ekonomski fakultet.

[37] Tang, J., Tang, Z., \& Cowden, B. J. (2017). Exploring the Relationship Between Entrepreneurial Orientation, CEO Dual Values, and SME Performance in State Owned vs. Nonstate Owned Enterprises in China. Entrepreneurship Theory and Practice, 41(6), 883-908. DOI: 10.1111/etap.12235

[38] Thornberry, N. (2006). Lead Like an Entrepreneur: Keeping the Entrepreneurial Spirit Alive within the Corporation. Fairfield, PA: McGraw Hill.

[39] Tovstiga, G., \& Tulugurova, E. (2007). Intellectual capital practices and performance in Russian enterprises. Journal of Intellectual Capital, 8(4), 695-707. DOI: 10.1108/14691930710830846

[40] Townsend, D.M., Busenitz, L.W. and Arthurs, J.D. (2010). To Start Or Not To Start: Outcome and Ability Expectations in the Decision to Start a New Venture. Journal of Business Venturing, 25, 192-202. DOI: 10.1016/j.jbusvent.2008.05.003

[41] Unger, J. M., Rauch, A., Frese, M., \& Rosenbusch, N. (2011). Human capital and entrepreneurial success: A meta-analytical review. Journal of business venturing, 26(3), 341-358. DOI: 10.1016/j.jbusvent.2009.09.004

[42] Wang, C. L., Tee, D. D., \& Ahmed, P. K. (2012). Entrepreneurial leadership and context in Chinese firms: A tale of two Chinese private enterprises. Asia Pacific Business Review, 18(4), 505-530. DOI: $10.1080 / 13602381.2012 .690257$

[43] Watson, R., Storey, D. J., Wynarczyk, P., Keasey, K., \& Short, H. (1994). The remuneration of non owner managers in small and medium sized UK enterprises. Journal of Management Studies, 31(4), 553-568. DOI: 10.1111/j.1467-6486.1994.tb00630.x

[44] Wiklund, J., \& Shepherd, D. (2003). Knowledge based resources, entrepreneurial orientation, and the performance of small and medium sized businesses. Strategic management journal, 24(13), 13071314. DOI: $10.1002 / \mathrm{smj} .360$

Received: 2019-03-20

Revisions requested: 2019-11-02

Revised: 2020-02-09

Accepted: 2020-05-05 


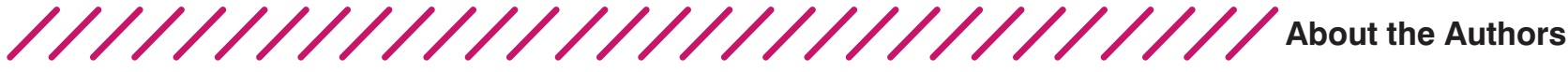

\author{
Marijana Simić \\ University of Kragujevac, Faculty of Economics, Serbia \\ e-mail:msimic@kg.ac.rs
}

Marijana Simic is a Ph.D student at the Department for Management and Business Administration, Faculty of Economics, University of Kragujevac. In September 2016 she received her bachelor's degree. She defended her bachelor thesis entitled: "Employee Motivation with the Purpose of Improving Organizational Performance", at the Faculty of

Economics, University of Kragujevac. The topic of her Master's thesis was related to human capital and entrepreneurship, and in October 2017 she received her master's degree. Main fields of her research interest are human resources, entrepreneurship and organizational behavior. She was awarded a scholarship: Dositej's fund for Young Talents by the Ministry for Youth and Sports. She is engaged as a young researcher at the project of Ministry of Education, Science and Technological Development of the Republic of Serbia. Also, as a young researcher she has participated in several international scientific conferences.

\section{Marko Slavković University of Kragujevac, Faculty of Economics, Serbia e-mail: mslavkovic@kg.ac.rs}

Marko Slavkovic is an assistant professor at the Faculty of Economics University of Kragujevac. He received his Ph.D. at the Faculty of Economics in Kragujevac in the field of Strategic Human Resource Management. He holds the following subjects at graduate, master and doctoral academic studies: Human Resource Management, International Human Resource Management and Strategic Management in Tourism. He

participated in the preparation of a number of analyses, studies and projects for the needs of the subject of economy. As a consultant, he has been engaged permanently or occasionally by domestic and foreign companies. He is currently serving as Vice Dean for Science at the Faculty of Economics in Kragujevac. He is a member of the Executive Committee of the Economist Society of Kragujevac.

\section{Vesna Stojanović Aleksić University of Kragujevac, Faculty of Economics, Serbia e-mail: vesnasa@kg.ac.rs}

Vesna Stojanović-Aleksić, PhD, is a Full Professor at the Department for Management and Business Economics. She holds PhD degree from the Faculty of Economics, University of Kragujevac and teaches the following subjects at the same university: Organization of Enterprise, Organizational Behavior and Leadership and Organizational Changes. Her research areas are: leadership, organizational culture, organizational change, organizational behaviour and corporate social responsibility.
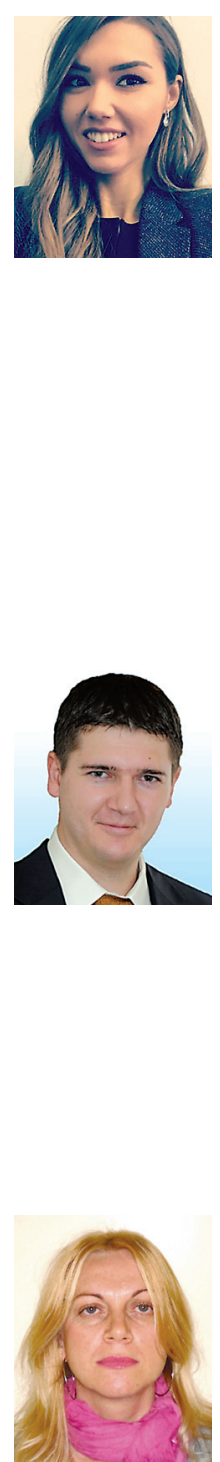